\title{
Reading Syed Abdul Malik's Dhanya Nara Tanu Bhal and Rudrani Sarma's Lauhitya Tirar Amrit Gatha in the light of Assamese Vaishnavite Hagiography
}

Dhurjjati Sarma $^{\dagger}$

\begin{abstract}
As part of the pan-Indian Bhakti movement, the Neo-Vaishnavite movement sought to reform the decadent modes of worship practiced in medieval Assam and, in the process, moved beyond the religious confines of the sectarian domain to influence the socio-cultural life of the milieu to which it addressed itself. An important document which enables a reading pertaining to the stated framework is the hagiography. In a hagiographic tradition, the biographical account of the saint is continually juxtaposed with the socio-cultural ethos of the contemporary spatio-temporal frameworks.

Key words: Hagiography, Neo-Vaishnavism, Sankardeva, Social Energy, Self-Fashioning, Dhanya Nara Tanu Bhal, Lauhitya Tirar Amrit Gatha, Assam, India
\end{abstract}

\footnotetext{
${ }^{\dagger}$ Assistant Professor of Comparative Indian Literature, Department of Modern Indian Languages and Literary Studies, Gauhati University, Assam, Email: dhurjjati.sarma@gmail.com

(C) 2016 Sarma. This is an Open Access article distributed under the terms of the Creative Commons Attribution License (http://creativecommons.org/licenses/by/2.0), which permits unrestricted use, distribution, and reproduction in any medium, provided the original work is properly cited.
} 


\section{Introduction}

In the context of colonialism and the evolving forms of national and regional identities in the period following Indian independence, the lives of the medieval saints, including Sankardeva in Assam, have been 'fashioned' as part of the culturisation process whereby they are elevated to the status of 'cultural icons' representing the ethos of modern cultural identity. This article undertakes to examine this phenomenon through a comparative analysis of two Assamese novels of postIndependence India-Syed Abdul Malik's Dhanya Nara Tanu Bhal (1987) and Rudrani Sarma's Lauhitya Tirar Amrit Gatha (2015)-in the light of the 'standard' Assamese Vaishnavite Hagiography, namely, the GuruCharit-Katha (ed. Maheswar Neog, 1987), and Lakshminath Bezbaroa's Sankardeva aru Madhavdeva (1914).

The article attempts to theorise the aforementioned comparative analysis on the basis of Stephen Greenblatt's understanding of the collective experience of the society as discerned in the circulation of 'social energy' in Renaissance England. The ideas developed by Greenblatt through his analyses are extended hereby to an understanding of the medieval Assamese Vaishnavite hagiographical tradition of Guru-Charit-Katha and Lakshminath Bezbaroa's early twentieth-century 'modern' biographies of Sankardeva and Madhavdeva on similar lines. In the subsequent section of the article, the two aforementioned novelsDhanya Nara Tanu Bhal and Lauhitya Tirar Amrit Gatha-are discussed in the light of the 'fashioning' of the lives of the medieval saints as part of the Assamese identity-formation process in the modern period.

Stephen Greenblatt, in the preface to his muchacclaimed book Will in the World: How Shakespeare Became Shakespeare, hints towards a possible way to decode the mystery surrounding the life and works of William Shakespeare.

To understand who Shakespeare was, it is important to follow the verbal traces he left behind back into the life he lived and into the world to which he was so open. And to understand how Shakespeare used his imagination to transform his life into his art, it is important to use our own imagination. (Greenblatt, 2004: 14)

In the aforementioned book, Greenblatt puts together the extant traces and fragments of Shakespeare's life and whatever evidence that could be gleaned from the poems and plays composed by him in order to write a compelling biographical narrative and, as remarked by David Walton of St. Petersburg Times, "one of the most persuasive reconstructions of Shakespeare's life and career". In an earlier book, Shakespearean Negotiations: The Circulation of Social Energy in Renaissance England (1988), Greenblatt made his intentions amply, though a bit morbidly, clear that he intended to speak with the dead. And in his attempt to re-create a conversation with them, he says: "I could hear only my own voice, but my own voice was the voice of the dead, for the dead had contrived to leave textual traces of themselves, and those traces make themselves heard in the voices of the living" (Greenblatt, 1988: 1).

\section{Guru-Charit-Katha: An Assamese Vaishnavite Hagiography}

Considering Greenblatt's formulation with respect to Shakespeare and the recovery of his 'dead' voice, we may similarly argue that the indigenous charita and gatha writing traditions in India have also committed themselves to the hallowed purpose of 'preserving' and 'disseminating' the voices of the 'dead' saints and religious heads, and thereby, on many occasions, have 'reconstructed' their 'lives' on the basis of existent lores and popular narratives of the day. The Assamese Vaishnavite Hagiographical tradition is no exception to the rule. Maheswar Neog, in his English Introduction to Guru-Charit-Katha, speaks of the Guru-lore as a ritual and a tradition. He says:

The GCK [Guru-Charit-Katha] tells us in the very start (§§ 1-2) how the 
celebration of the guru's life-story (gurujanar caritra-kirtana) came into being as a part of the prayer services in the Vaishnava temples (sattra) in the same style as the lores of Lord God (sriramar krisnabalabhadrar caritra) when Madhavadeva became the head of the Vaisnava Church (Neog, 1987: Introduction)

This tradition of narrating the life-stories of Mahapurush Srimanta Sankardeva and that of Madhavdeva after his death had continued well into the late nineteenth century. Lakshminath Bezbaroa, in his memoir entitled Mor Jeevan Xuworan, refers to the observance of the 'Carita Tola' ritual whereby the lives of the saints were narrated with the avowed purpose of re-creating their lives in the imagination of the bhaktas. In this context, it needs to be noted that the Guru-Charit-Katha may have been transmitted to written form only towards the middle part of the eighteenth century, as evident from the fact that Cakrapani Vairagi Atai, who has been credited as the probable narrator of the hagiographical narrative, lived till 1758 AD (Neog, 1987). All this point towards the fact that life-stories of the two gurus have been in social circulation for at least a hundred and fifty years (Sankardeva passed away in 1568 AD while Madhavdeva lived till 1596). Therefore, by the time the 'text' of the narrative was codified into the written form, it had ceased to be the perfect and substitutable signifier of the 'life' it had intended to simulate.

Simulations, as understood by Greenblatt to be 'formal, self-conscious miming of life', are "undertaken in full awareness of the absence of the life they contrive to represent, and hence they may skilfully anticipate and compensate for the vanishing of the actual life that has empowered them" (Greenblatt, 1988: 1). The narrative and performative components of the 'Carita Tola' ritual built upon the 'textual traces' left behind by the actual personae of Srimanta Sankardeva and Madhavdeva which were subsequently 'mimed' so as to satisfy the curiosity of the bhaktas to know more about the life of the gurus. However, being a part of the religious order that demanded continued allegiance of the bhaktas and unflinching loyalty towards the founder gurus, it was imperative for the succeeding Vaishnava prelates to use their own imagination in order to compensate for the increasing temporal distance between the founder gurus and the latter-day bhaktas.

Nevertheless, the presence of the 'imagination' as mentioned with respect to the simulative reconstruction of the life of the Vaishnava gurus as well as of Shakespeare mentioned in the opening passage of this paper should not be understood merely as rhetorical (or devotional) overstatement directed towards the recognition and commemoration of a 'numinous' authority in Sankardeva or Shakespeare. Instead, if we consider 'imagination' as the compelling power behind literary production, then we ought to agree with Greenblatt when he proposed a serious understanding of the collective production of literary pleasure and interest. For Greenblatt, this production is 'collective' since "language itself, which is at the heart of literary power, is the supreme instance of a collective creation" (Greenblatt, 1988: 4). Therefore, in this way, we may argue that the Guru-Charit-Katha, whether in the form of an oral 'text' in social circulation or a written text subsequently transmitted into the modern era of Assamese social and cultural history, was built upon the individual as well as collective beliefs and experiences of the members of the society. As a community, although they were bound by language, language itself became the very means of their cultural expression through different textualities.

\section{Lakshminath Bezbaroa and Assamese Vaishnavite Hagiographical Tradition}

Lakshminath Bezbaroa was born into a family which was deeply ingrained in the value system prescribed by the Vaishnavite religious order. He wrote biographies of the saints, the first one 'Sankardeva' (1911) and 'Mahapurush Sankardeva and Madhavdeva' (1914). In his preface to the second edition of the latter, Bezbaroa wrote: 
I have observed that even among those who are conversant with the lives of the Mahapurushas, there is a tendency to take the corrupt and inaccurate versions forwarded by some petty biographers as gospel truth. If the biographer does not respect the subject, the representation lacks life; for his reasoning and perspective will almost always be insensitive. (Trans. Bibhash Choudhury)

He felt that in order to do justice to a biographical representation, one needed to develop a kind of inwardness in relation to the subject and also subscribing to the worldview propagated by the saints. In Bezbaroa's case, such an affiliation came naturally to him owing to the reasons already cited above.

It is to be noted that Bezbaroa's writings on Sankardeva were not limited to the two biographies. He wrote numerous articles in his journal 'Banhi' where he took an objective stance in addressing misconceptions concerning the life and teachings of the saints. If his hagiographies served a revivalist purpose in strengthening the Neo-Vaishnavite base of the modern Assamese society, his related writings on the topic address contemporary issues concerning the socio-cultural historiography of Assam. In relation to Bezbaroa's analytical perspectives in Sankardeva studies, a noted scholar K.N. Phukan (1996: 142) remarked that:

Bezbaroa's re-discovery of Sankaradeva was inspired partly by the wish to affirm by celebration the joy of faith and partly in order to identify in neo-Vaishnavism a foundation of the expansive and importunate ethos of the Assamese as a distinct nationality in the combined terms of a common faith, culture, language and a vaguely defined and standoffish political temper.

\section{Dhanya Nara Tanu Bhal and Lauhitya Tirar Amrit Gatha}

In the context of colonialism and the evolving forms of national and regional identities in the period following Indian independence, the lives of the medieval saints, including Sankardeva in Assam, have been 'fashioned' as part of the culturisation process whereby they are elevated to the status of 'cultural icons' representing the ethos of modern cultural identity. The role of Bezbaroa vis-à-vis his contribution towards the revival of Sankardeva studies in the early twentieth century is a case in point.

This paper now moves on to engage itself with a relatively new kind of literary scholarship in Assamese, i.e. the genre of 'biographical novel' in Assamese, especially the one dealing exclusively with the 'lives' of Sankardeva and Madhavdeva. Medini Choudhury's Banduka Behar (1976) was the first of the kind mentioned above. Syed Abdul Malik has two such novels to his credit: Dhanya Nara Tanu Bhal (1987) and Prem Amritara Nadi (1999). Lakshminandan Bora, on the other hand, has also written two novels in the aforementioned genre: Jakeri Nahike Upam (1993) and Xehi Gunabidhi (1999). The latest addition to the genre is the novel Lauhitya Tirar Amrit Gatha (2015) by Rudrani Sarma. These novels would also fall somewhat under the rubric of socialhistorical novel. In this respect, they would mark a departure from the preceding hagiographic tradition. With their emphasis upon the Vaishnava saints as being protagonists of a narrative storyline and, henceforth, contingent to the specific objectives of the novelist, these novels promise somewhat alternative perspectives on the chosen protagonists.

Having chosen Dhanya Nara Tanu Bhal and Lauhitya Tirar Amrit Gatha for analysis, we ought to follow the 'verbal traces' that led the respective authors towards a fictional reconstruction of the life of Sankardeva. While Lakshminath Bezbaroa and Lakshminandan Bora have, in their prefaces, claimed their upbringing within the Vaishnavite religious order as a compelling force behind the composition of their works, no such claims are perceptible in the case of Syed Abdul Malik or Rudrani Sarma. Interestingly, Malik dedicates his book to the indomitable spirit of Jyotiprasad 
Agarwalla who, according to him, endeavoured to establish Sankardeva as the symbol and representative of the art, literature and culture as well as of a new generation of people. On the other hand, Rudrani Sarma has not written a preface to her novel. Instead she begins with a short verse prologue where she refers to the immortal literary creations of Sankardeva as imbued with the 'social energy' that would continue to energise the mind and spirit of the larger Assamese community. The ever-flowing waters of the Brahmaputra shall forever stand as a witness to this collective experience of the society.

It is, precisely, this collective experience of the society that we can discern in the circulation of 'social energy'. Social energy, for Greenblatt (1988: 6), can be identified or is manifested primarily through its effects - "in the capacity of certain verbal, aural, and visual traces to produce, shape, and organize collective physical and mental experiences". However, it is important that the aesthetic or literary forms of social energy are equipped with a certain degree of adaptability which would enable them to survive and withstand the manifold changes brought about by social and cultural events in history. He further says: "Whereas most collective expressions moved from their original setting to a new place or time are dead on arrival, the social energy encoded in certain works of art continues to generate the illusion of life for centuries" (Greenblatt, 1988: 7).

Abdul Malik's Dhanya Nara Tanu Bhal, as a social-historical novel, has sustained as well as transmitted the 'social energy' generated out of the 'original setting' in medieval Assam through a simultaneous engagement with the various discursive practices, including, for instance, the one pertaining to the preparation of manuscripts out of aloe or eagle-wood (sanchi paat), local ink made out of myrobalan (xilikha) and use of reed (khagari) as handmade pen. Now these are apparently disconnected or isolated details that have little or no bearing upon the narrative structure of the novel. But it bears testimony to the author's larger perception of the 'physical and mental experiences' in operation at that time in Assamese social and cultural history. In a way, we may argue that he was intent on analysing the discursive shifts that have occurred through history and which manifest themselves in the regularities in particular activities and their interpretations across a range of sciences.

Michel Foucault, in his introduction to The Order of Things (1970: xi), expresses his desire to "reveal a positive unconscious of knowledge: a level that eludes the consciousness of the scientists and yet is part of scientific discourse, instead of disputing its validity and seeking to diminish its scientific nature...I have tried to reveal, by isolating, as their specific locus, a level that I have called, somewhat arbitrarily perhaps, archaeological". A detailed and indepth of Dhanya Nara Tanu Bhal would enable us to generate and isolate many more instances of the author's engagement with the underlying discursive structures as well as their encoding of the 'social energy' as part of the larger process of culturisation. The same task may be undertaken with respect to Lauhitya Tirar Amrit Gatha as an attempt by the author Rudrani Sarma to explore and interpret the 'traces' left behind by the 'hallowed dead' of the yesteryears and which have continued to energise the social and cultural sensibility of the inhabitants spread on both sides of the Brahmaputra.

\section{References}

Foucault, Michel. 1970. The Order of Things: An Archaeology of the Human Sciences. London: Tavistock.

Greenblatt, Stephen. 1988. Shakespearean Negotiations: The Circulation of Social Energy in Renaissance England. Berkeley and Los Angeles: University of California Press.

Greenblatt, Stephen. 2004. Will in the World: How Shakespeare Became Shakespeare. New York and London: W.W. Norton \& Company.

Malik, Syed Abdul. 1987. Dhanya Nara Tanu Bhal. Guwahati: Student's Store. 
Neog, Maheswar (ed.). 1987. Guru-CharitKatha. University Publication Department: Gauhati University.

Phukan, K.N. 1996. 'Bezbaroa's Analytical Perspectives in Sankaradeva Studies'. In Ranjit Kumar Dev Goswami (ed.), Essays on Sankaradeva. Guwahati: Forum for Sankaradeva Studies and Lawyer's Book Stall, pp.138-160.

Sarma, Rudrani. 2015. Lauhitya Tirar Amrit Gatha. Guwahati: Bishal Prakashan. 